\title{
Sistem Pembayaran Otomatis Berbasis Contactless Smartcard Dengan Teknologi RFID di Kantin SMK Taman Harapan Bekasi
}

\author{
Ayu Dian Kristanti ${ }^{1}$, Didik Setyadi ${ }^{2, *}$ \\ * Korespondensi: e-mail: ddk.setiyadi20@gmail.com
}

1 Teknik Informatika, Universitas Bina Insani; Jl. Siliwangi No 6 Rawa Panjang Bekasi Timur 17114 Indonesia, Telp. (021)824 36886 / (021) 82436996. $\begin{array}{lllll}\text { Fax. } & \text { (021) } & 824 & 009 & 24 ;\end{array}$ ayudiankristanti@gmail.com

2 Informatika, Universitas Indonesia Mandiri; Jl. Jendral Sudirman KM 31 Kranji, Bekasi Jawa Barat, Telp 02189468034; e-mail: ddk.setiyadi20@gmail.com

Submitted : 23 September 2021

Revised : 15 Oktober 2021

Accepted : 4 November 2021

Published : $\mathbf{3 0}$ November 2021

\begin{abstract}
During a pandemic, we must reduce physical contact both with other people and with objects around us. With automatic payments using RFID technology based on the Internet of Things and websites to minimize physical contact (contactless smartcards) and minimize fraud in transactions. The system uses RFID sensors, Nodemcu esp8266, Jumper cables, I2c LCDs, and databases. Using the Prototype method that works continuously through collaboration between users and analysts. The contactless smartcard system at the SMK Taman Harapan Bekasi canteen can make transactions easier in the canteen. The contactless smartcard was created using the NodeMCU Esp8266 by utilizing the rfid mifare522 sensor as a tag detector so that it can facilitate the buying and selling process, for monitoring it has used a website with data that has been automatically stored in the database to find out canteen and admin user information and transaction history is saved to the database in real time.
\end{abstract}

Keywords: Database, Intenet of Things, Nodemcu esp8266, RFID, Web Service.

\section{Abstrak}

Pada masa pandemi kita harus mengurangi kontak fisik baik dengan orang lain maupun dengan benda disekitar. Dengan pembayaran otomatis menggunakan teknologi RFID berbasis Internet of Things dan website untuk meminimalisir kontak fisik (contactless smartcard) dan meminimalisir kecurangan dalam bertransaksi. Sistem menggunakan Sensor RFID, Nodemcu esp8266, kabel Jumper, Lcd I2c, dan database. Menggunakan metode Prototype yang bekerja yang secara terus menerus melalui kerjasama antara user dan analis. Dengan Sistem contactless smartcard di Kantin SMK Taman Harapan Bekasi dapat mempermudah transaksi di kantin. Contactless smartcard dibuat menggunakan NodeMCU Esp8266 dengan memanfaatkan rfid mifare522 sensor sebagai pendeteksi tag sehingga dapat memudahkan proses jual beli, untuk monitoringnya sudah menggunakan website dengan data yang sudah otomatis tersimpan dalam database untuk mengetahui informasi user kantin dan admin serta history transaksi disimpan ke database secara realtime.

Kata kunci: Database, Intenet of Things, Nodemcu esp8266, RFID, Web Service. 


\section{Pendahuluan}

Perkembangan teknologi sistem pada komputer dan Internet memberi dampak terhadap munculnya inovasi dalam pembayaran elektronik (electronic payment). Dengan kemudahan akses via Internet dan tanpa antrian menjadi alasan makin populernya layanan (elektronik) ini. Berbagai cara pembayaran elektronik antara lain mobile banking, Internet banking, dan pembayaran dengan kartu kredit atau debit. Konsep cara pembayaran elektronik yaitu terhubung langsung dengan rekening pengguna. Untuk setiap instruksi pembayaran perlu persetujuan dari pengguna dan jika ada biaya transaksi akan dibebankan langsung ke rekening pengguna. Dengan demikian seseorang yang memiliki uang elektrik sama dengan memiliki uang tunai. Namun nilai uang tersebut telah dikonversikan ke dalam bentuk elektronik. Untuk mengamankan transaksi uang elektrik perlu digunakan otentikasi pengguna sistem untuk menjamin kerahasiaan data transaksi nasabah (confidentiality) dan enkripsi data transaksi untuk menjamin privasi pengguna, penyedia layanan, dan transaksi. Oleh karena itu perlu dibuat suatu aplikasi pendukung yaitu aplikasi sistem penukaran mata uang tradisional yang menggunakan teknologi NFC untuk penyetoran uang elektronik. Aplikasi sistem penukaran mata uang tradisional ini dapat dengan mudah membayar sehingga tidak perlu membawa uang tunai (Aziz, 2015).

Teknologi RFID merupakan teknologi untuk mengidentifikasi data melalui komunikasi gelombang elektro magnetik. Teknologi ini terdiri dari perangkat pembaca dan tag yang berupa barcode atau smartcard. RFID memiliki kemampuan untuk mengirim data yang bersih dan reliable yang dibutuhkan sebagai input untuk perangkat lunak pada sistem pembayaran otomatis. Selain itu karena kemudahan dalam bertransaksi, sistem pembayaran elektronik menawarkan keringanan biaya transaksi, salah satu metode pembayaran elektronik, yaitu sistem e-money dan aplikasi prototype menggunakan contactless smartcard dengan teknologi RFID (Utomo et al., 2016).

Sekolah SMK Taman Harapan masih menggunakan sistem pembayaran uang tunai dalam transaksi jual beli di kantin. Sistem pembayaran uang tunai tergolong sebagai pembayaran secara manual memiliki kelemahan yaitu tidak praktis, dalam hal ini proses transaksi yang masih konvensional dengan uang sering kali terjadi kesalahan dalam proses transaksi. Salah satu kekurangan sistem manual ini yaitu terjadi kecurangan dan kesalahan dalam proses transaksi yang dilakukan oleh siswa/i, siswa/i atau warga sekolah pada saat bertransaksi membeli sesuatu di kantin, maupun membutuhkan waktu untuk membayar dan memberikan kembalian (Zikri et al., 2018).

Selain itu, karena masa pandemi dimana harus mengurangi kontak fisik baik dengan orang lain maupun dengan benda disekitar. Dengan adanya sistem pembayaran otomatis menggunakan teknologi RFID memiliki kemampuan untuk meminimalisir kontak fisik (contactless) dan meminimalisir kecurangan dalam bertransaksi.

Teknologi RFID (Radio Frequency Identification) merupakan teknologi Auto ID (Automtic Identification). Auto ID digunakan buat melakukan sosialisasi otomatis, seperti 
barcode sistem, RFID digunakan menyimpan dan mendapatkan data menggunakan tag dan reader (Jadid, 2017). RFID juga disebut transceiver yang membaca sinyal radio dan memindahkan information bulletin, komputer atau suatu perangkat. Alat pembaca dapat digenggam atau tertanam dalam objek (Paulus et al., 2013). Tag atau kartu adalah perangkat yang terbuat dari sirkuit elektronik dan antena yang terintegrasi dalam sirkuit. Urutan tag biasanya memiliki memori, sehingga tag memiliki kapasitas penyimpanan. RFID, juga dapat membaca dan menulis berulang kali (Paulus et al., 2013).

Mikrokontroller sebuah chip mikrokomputer yang secara fisik berupa IC (integrated circuit). Mikrokontroler biasanya beroperasi berdasarkan program yang disematkan (software) program aplikasi yang dibutuhkan. NodeMCU adalah platform loT open source mirip dengan board Arduino ESP826. NodeMCU menggabungkan ESP8266 menjadi sebuah compact board dengan berbagai fungsi, seperti mikrokontroler dan akses komunikasi USB ke serial, sehingga dapat diprogram hanya dengan memperpanjang kabel data Micro USB. Modular Wifi NodeMCU adalah firmware LUA espressif ESP82266 Wifi SoC. NodeMCU adalah platform loT open source. Ini terdiri dari perangkat keras berupa system-on-chip (SoC). Dapat juga cancel programming Dengan Bahasa C Menggunakan Arduino IDE (Wicaksono, 2017) Arduino IDE adalah perangkat lunak yang ditulis dalam bahasa Java. Arduino IDE meliputi: editor program, jendela yang memungkinkan pengguna untuk menulis dan mengedit program dalam bahasa pemrosesan, kompiler, modul yang mengubah kode program (bahasa pemrosesan) menjadi kode biner, pengunggah, dan jendela untuk memuat biner.

Internet of Things (IOT) memiliki konsep untuk memperluas manfaat dari koneksi Internet yang terhubung dan persisten. Internet of Things (IOT) digunakan dalam jaringan untuk mengontrol perangkat elektronik, yang dapat dikontrol dari jarak jauh melalui Internet (Efendi, 2018), pada penelitian ini digunakan mikrokontroller dengan menggunakan NodeMCU esp8266 untuk sistem pembayaran dengan sensor dan tag RFID.

\section{Metode Penelitian}

Flowchart atau bagan alir, awal mulanya memang berkembang dari industri komputer yaitu untuk menggambarkan.urutan.proses penyelesaian masalah Metode yang digunakan adalah Prototype merupakan proses iteratif dalam pengembangan sistem (Dewobroto, 2005), demikian pula pada sistem pembayaran otomatis berbasis contactless smartcard dengan teknologi RFID ini. Dalam proses ini, kebutuhan menjadi sistem kerja, yang terus ditingkatkan melalui kolaborasi antara pengguna dan analis. Berbagai alat pengembangan juga dapat digunakan untuk membangun prototype untuk menyederhanakan proses (Maharto \& Ambarita, 2012). Tujuan dari pembuatan prototype pengembang sistem adalah untuk mengumpulkan informasi dari pengguna sehingga pengguna dapat berinteraksi dengan model prototype yang dikembangkan. Metode ini sesuai untuk pengembangan sistem skala kecil dan besar, diharapkan proses pembangunan dapat berjalan dengan baik, berjalan tertib dan selesai tepat waktu. Kelebihan prototype adanya komunikasi antara pengembang dan pelanggan. Sehingga 
pengembangan menjadi mudah karena pemakai mengetahui yang diharapkan (Syaddad, 2017).

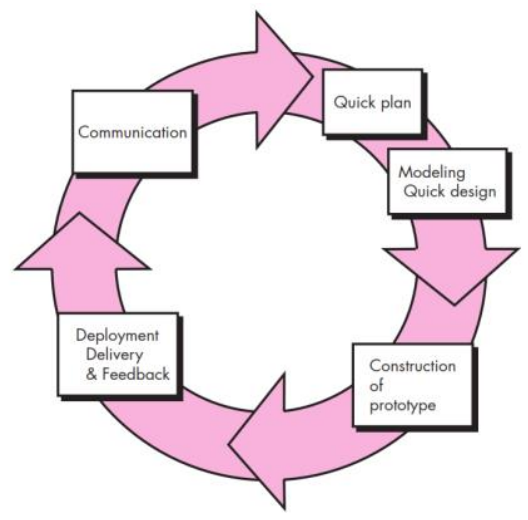

Sumber: Pressman (2010)

\section{Gambar 1 Fase Prototype}

Sebagaimana pada gambar 1, fase metode prototype adalan (a) Fase Communication, yaitu developer dan klien bertemu, dan kemudian menentukan tujuan keseluruhan, persyaratan yang diperlukan, dan gambaran umum tentang bagian yang diperlukan berikutnya; (b) Fase Quick Plan, yaitu perancangan dieksekusi dengan sangat cepat dan mewakili semua aspek perangkat lunak yang diketahui. Desain ini menjadi dasar pembuatan prototype; (c) Fase Modelling Quick Design, fokus pada representasi perangkat lunak (software) yang dapat dilihat oleh pengguna/pelanggan. Pemodelan desain cepat cenderung ke desain prototype; (d) Construction of Prototype, membuat framework atau prototype design dari software atau software yang akan dibangun; (e) Fase Deployment Delivery \& Feedback, prototype yang dibuat oleh pengembang akan diberikan kepada pengguna untuk dievaluasi, kemudian pelanggan akan memberikan umpan balik untuk memodifikasi kebutuhan perangkat lunak yang akan dibangun.

\section{Hasil dan Pembahasan}

\subsection{Perancangan Perangkat Keras (Hardware)}

Perangkat keras (hardware) pada penelitian ini terdiri dari NodeMCU esp8266, tag RFID mifare-RC522, Tablet Android, LCD i2C, Laptop. Penjelasan hasil pembuatan alat perangkat keras (hardware) dapat dilihat pada Gambar 2.

Sumber: Hasil Penelitian (2021)

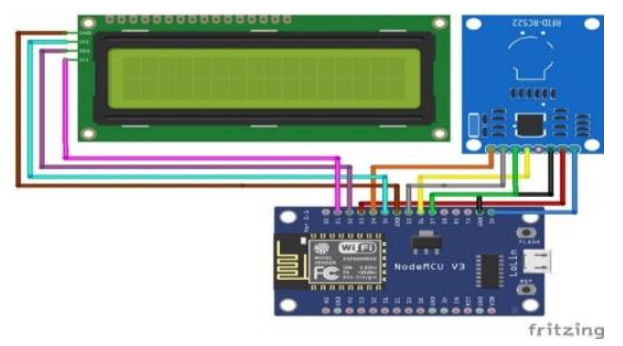

Gambar 2. Rangkaian Sistem Pembayaran Otomatis Contactless Smartcard 
Keterangan rangkaian sistem pada gambar 2 selengkapnya dijelaskan pada Tabel 1.

Tabel 1. Tabel Keterangan Fungsi Perangkat Keras

\begin{tabular}{ll}
\hline & Keterangan \\
\hline &
\end{tabular}

Sumber: Hasil Penelitian (2021)

\subsection{Perancangan Perangkat Lunak (Software)}

Perancangan perangkat lunak ini terdiri dari rancangan skema keseluruhan sistem perangkat lunak, use case diagram, activity diagram, Sequence Diagram, Class Diagram, Flowchart, dan Perancangan sketsa antarmuka website aplikasi. Flowchart cara kerja alat dan sistem dijelaskan pada gambar 3.

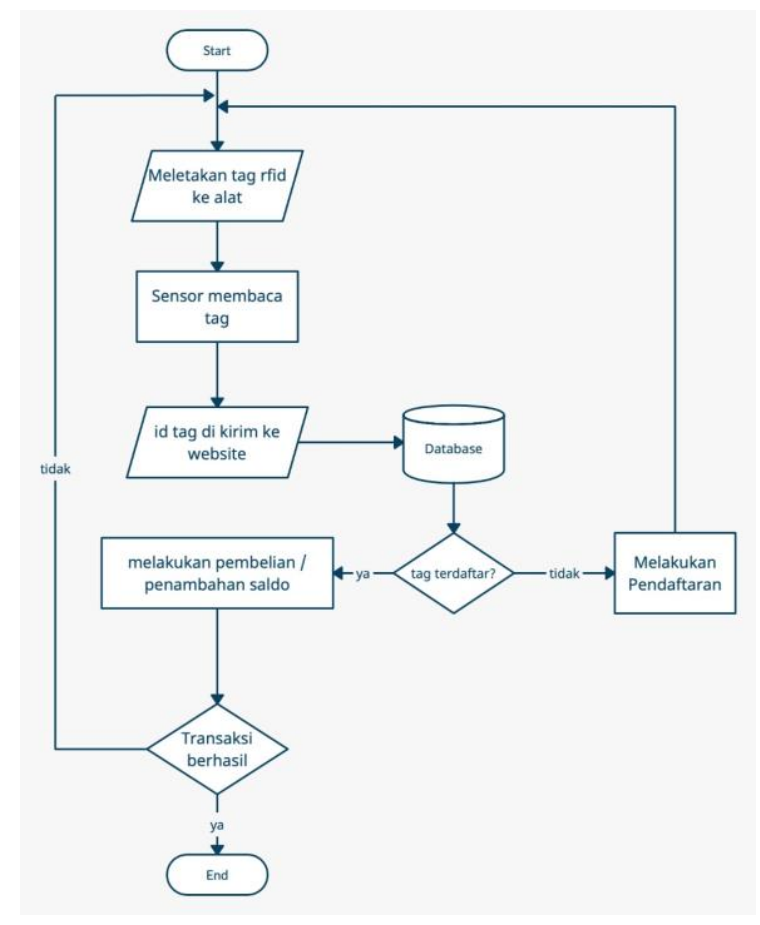

Sumber: Hasil Penelitian (2021)

Gambar 3. Flowchart Sistem Pembayaran Otomatis Contactless Smartcard 
Desain Perancangan Blok Diagram, untuk menjelaskan perancangan sistem yang dilakukan dalam mewujudkan penelitian membangun alat pembayaran otomatis berbasis contactless secara umum digambarkan oleh blok diagram sistem kerja yang ditunjukkan pada Gambar 4.

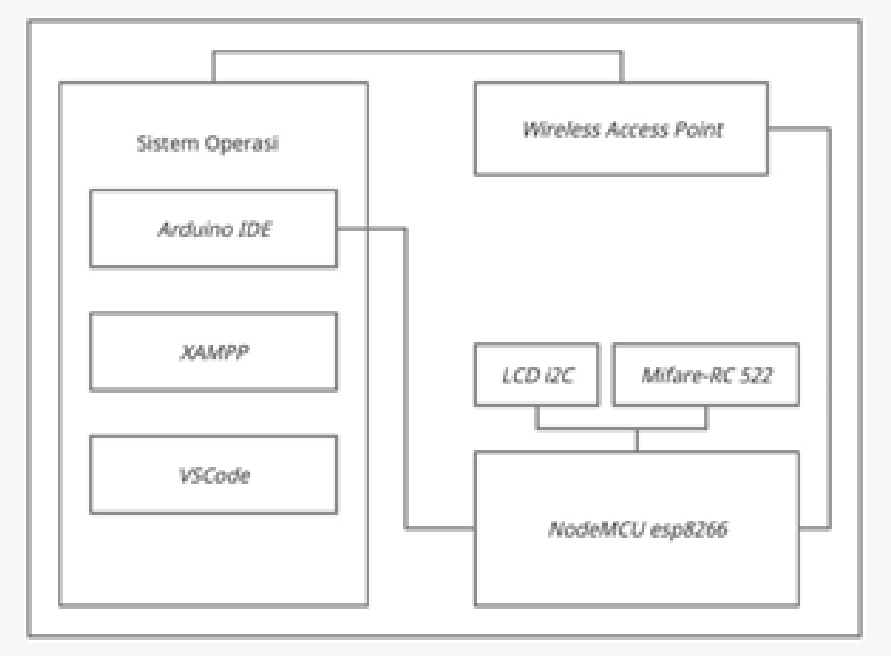

Sumber: Hasil Penelitian (2021)

Gambar 4. Diagram Blok Sistem Pembayaran Otomatis Berbasis Contactless Smartcard

Rancangan skema keseluruhan sistem perangkat lunak, bertujuan unuk mengambarkan alur dari skema perangkat lunak secara keseluruhan, sehingga dapat tergambar jelas alur dari mulai pembacaan tag RFID-MiFare522, menampilkan data kedalam dashboard dan data disimpan didalam database, seperti pada gambar 5 .

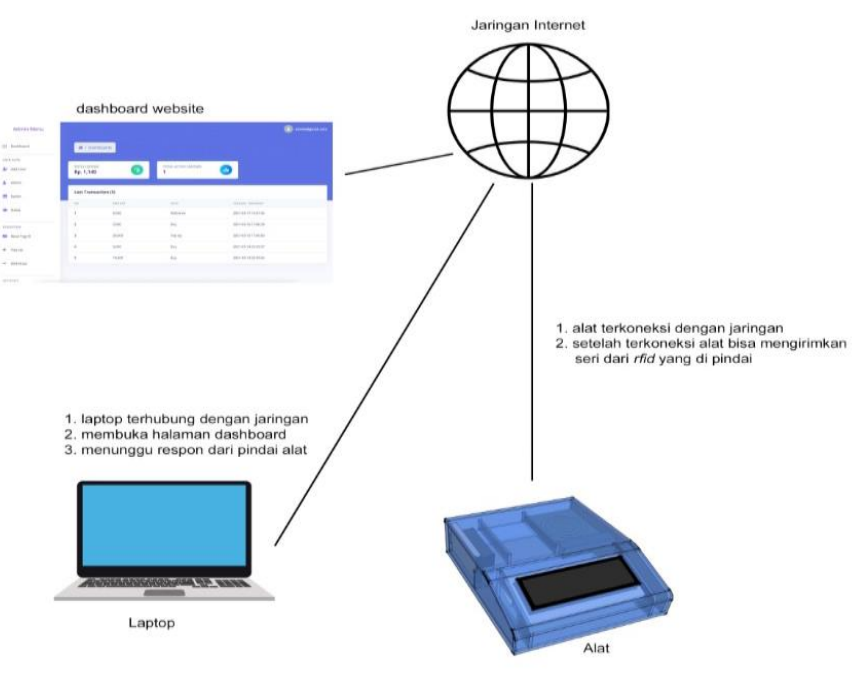

Sumber: Hasil Penelitian (2021)

Gambar 5. Rancangan Skema Keseluruhan Sistem Perangkat Lunak

\subsection{Implementasi Perangkat Keras (Hardware)}

Pada tahapan ini dilakukan pembuatan serta perakitan, alat pembayaran otomatis contactless smartcard sehingga dapat diimplementasikan prototype sesuai dengan kebutuhan, sebagaimana terlihat pada gambar 6 yang terdiri dari 3 bagian. 


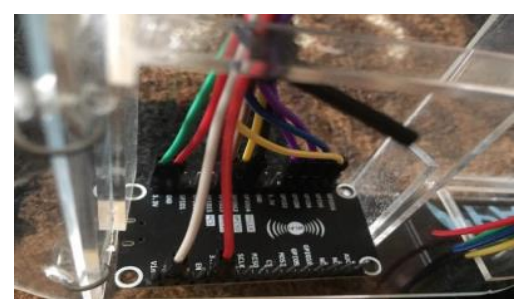

(a)

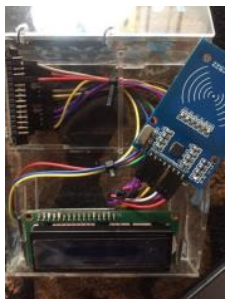

(b)

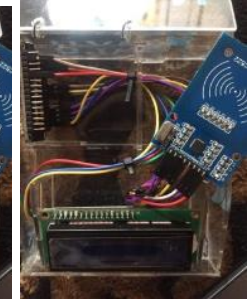

(c)

Sumber: Hasil Penelitian (2021)

Gambar 6. Implementasi Perangkat Keras (Hardware)

Gambar 6a merupakan implemetasi NodeMCU Mikrokontroler esp8266, dipasang dengan menggunakan cassing akrilik, jalur kabel dari NodeMCU ke modul-modul pendukung seperti $R F I D$ dan $L C D$.

Gambar 6b merupakan Implementasi sensor RFID dipasang pada bagian bawah casing dari alat sistem ini. Seperti pada perancangan terdapat 7 kabel yang terhubung ke NodeMCU yaitu Pin SDA pada module RFID-RC522 dihubungkan dengan pin D4 pada NodeMCU, Pin SCK pada module RFID-RC522 dihubungkan dengan pin D5 pada NodeMCU, Pin MOSI pada module RFID-RC522 dihubungkan dengan pin D7 pada NodeMCU, Pin MISO pada module RFID-RC522 dihubungkan dengan pin D6 pada NodeMCU, Pin GROUND (GND) pada module RFID-RC522 dihubungkan dengan pin GROUND (GND) pada NodeMCU, Pin RST pada module RFID-RC522 dihubungkan dengan pin D3 pada NodeMCU, Pin 3v3 pada module RFIDRC522 dihubungkan dengan pin 3v3 pada NodeMCU.

Gambar 6c merupakan implementasi $L C D$ i2c, LCD dipasang pada bagian depan casing alat sistem monitoring dengan posisi vertical, terdapat 4 kabel dari modul I2C yang sudah menyatu dengan LCD dihubungkan dengan NodeMCU yaitu kabel VCC, Ground, SCL dan SDA.

Area Hotspot untuk menghubungkan RFID Mifare-RC522 sebagai alat scan pembayaran otomatis dengan Access point. Supaya bisa berkomunikasi pengalamatan wireless access point ditanamkan di mikrokontroller supaya bisa terhubung dengan koneksi internet untuk mengirim data id RFID.

Implementasi hasil sensor menyimpan ke database dan ditampilkan ke website, Program hasil perhitungan dan penginputan dari sensor akan disimpan ke dalam database setelah itu ditampilkan ke website yang telah dibuat seperti pada gambar 7 .

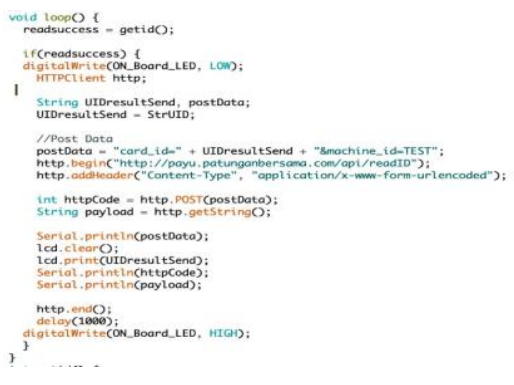

Sumber: Hasil Penelitian (2021)

Gambar 7. Program Menyimpan Data Sensor Kedalam Database 
Implementasi user interface, dilakukan sebagai tampilan sekaligus sarana untuk interaksi antara user dengan sistem monitoring yang dibuat. Hasil implementasi user interface sistem monitoring ini seperti pada gambar 8 .

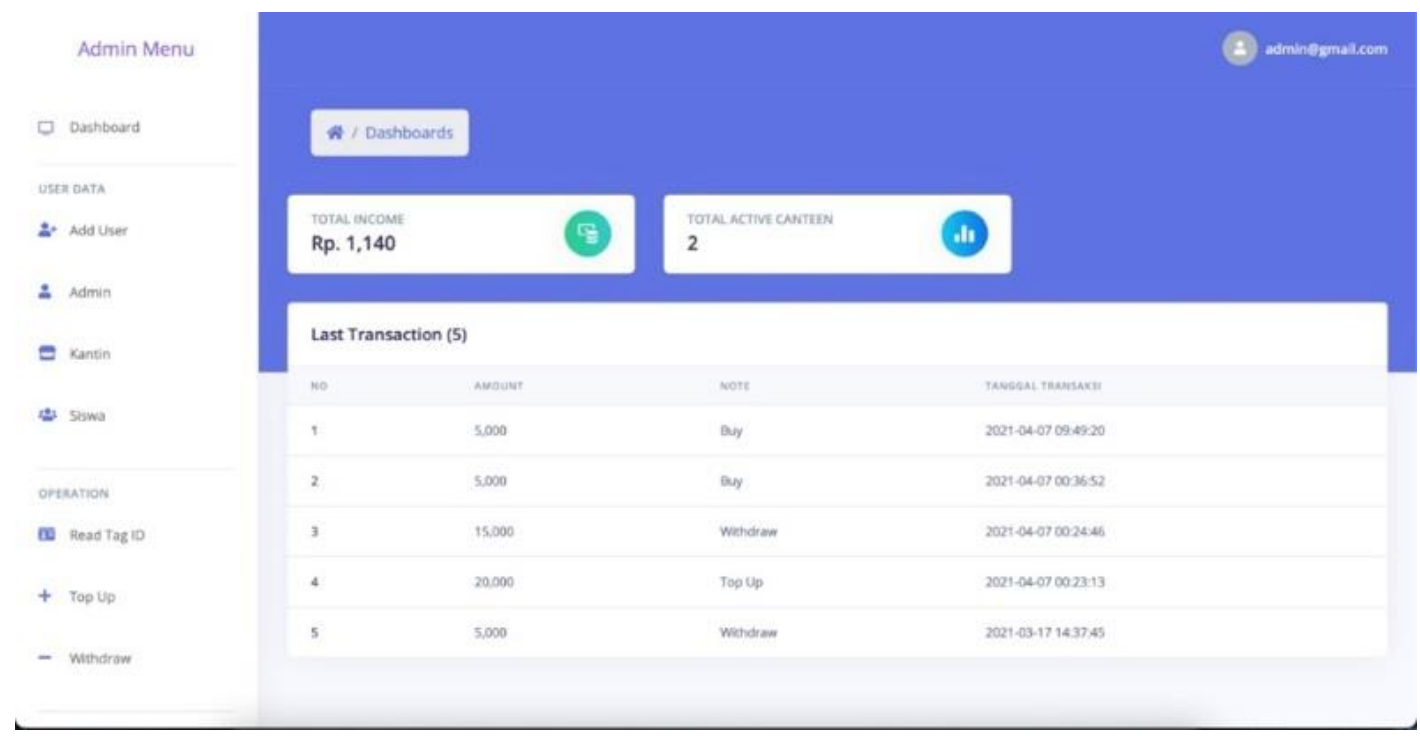

Sumber: Hasil Penelitian (2021)

Gambar 8. Tampilan User Interface Halaman Dashboard

\subsection{Pengujian Sistem Prototype}

Pengujian Sensor RFID Mifare522, pengujian sensor rfid dengan cara mendekatkan object dengan sensor Rfid dihubungkan ke mikrokontroler NodeMCU untuk input id setelah itu sistem akan mengirimkan informasi menuju ke mikrokontroller NodeMCU data tersebut kemudian disimpan ke database untuk ditampilkan di website secata realtime. Pengujian ini bertujuan untuk memastikan bahwa sensor RFID berfungsi untuk berkomunikasi ke NodeMCU. Hasil pengujian seperti pada tabel 2. Pengujian dilakukan dengan mendekatkan object pada sensor rfid dengan jarak yang ditentukan diantaranya jarak dari $0 \mathrm{~cm}-5 \mathrm{~cm}$ dan ditemukan fakta bahwa sensor RFID hanya dapat membaca jarak $\pm 3 \mathrm{~cm}$ untuk mendeteksi adanya tag $R F I D$. Lebih dari $3 \mathrm{~cm}$ maka tag RFID tidak bisa dibaca.

Tabel 2. Hasil Pengujian Tag Sensor RFID

\begin{tabular}{clll}
\hline No & Skenario Pengujian & Test Case & Hasil \\
\hline 1 & Memindai dari jarak $0 \mathrm{~cm}$ & Terdeteksi \\
& & & \\
& &
\end{tabular}

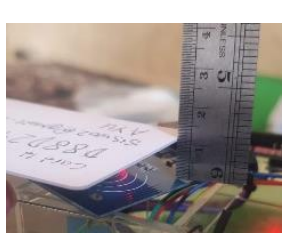

Terdeteksi 


\begin{tabular}{clll}
\hline No & Skenario Pengujian & Test Case & Hasil \\
\hline 3 & Memindai dari jarak $2 \mathrm{~cm}$ & Terdeteksi
\end{tabular}

\begin{tabular}{|c|c|c|}
\hline 4 & Memindai dari jarak $3 \mathrm{~cm}$ & Terdeteksi \\
\hline 5 & Memindai dari jarak $4 \mathrm{~cm}$ & $\begin{array}{l}\text { Tidak } \\
\text { Terdeteksi }\end{array}$ \\
\hline 6 & Memindai dari jarak $5 \mathrm{~cm}$ & $\begin{array}{l}\text { Tidak } \\
\text { Terdeteksi }\end{array}$ \\
\hline 7 & Memindai dari jarak $6 \mathrm{~cm}$ & $\begin{array}{l}\text { Tidak } \\
\text { Terdeteksi }\end{array}$ \\
\hline
\end{tabular}

Sumber: Hasil Penelitian (2021)

Pengujian hasil data sensor, setelah di pindai dan diinput oleh sensor RFID maka data tersebut akan masuk ke dalam website dan database, halaman dashboard bisa diakses dari jaringan internet lokal dengan browser. Tabel 3 memperlihatlkan tampilan dan hasil pengujian. 
Tabel 3. Tampilan Website Hasil Data Sensor.

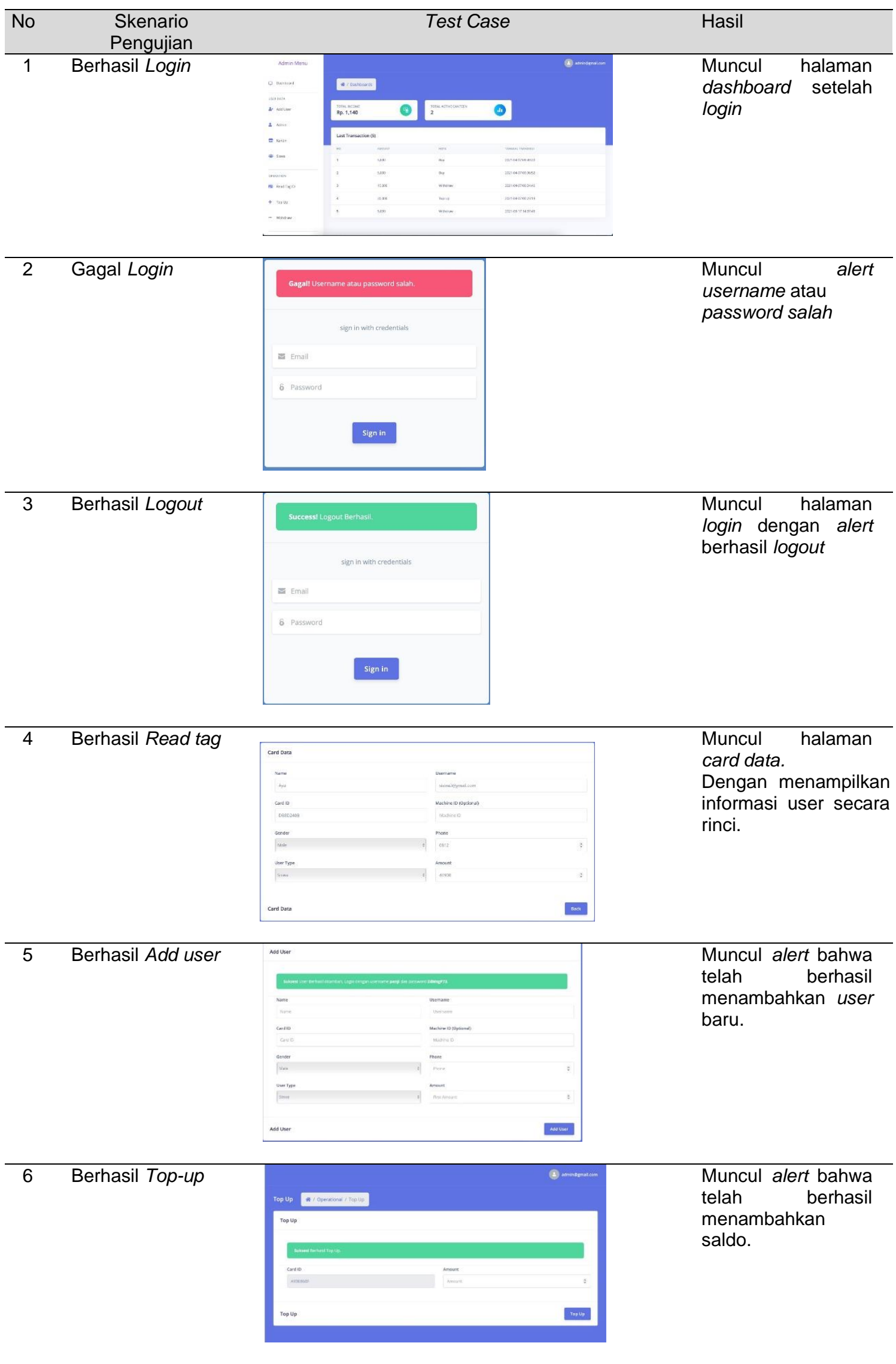




\begin{tabular}{|c|c|c|c|}
\hline No & $\begin{array}{l}\text { Skenario } \\
\text { Pengujian }\end{array}$ & Test Case & Hasil \\
\hline 7 & Berhasil Withdraw & = & $\begin{array}{l}\text { Muncul } \\
\text { alert } \\
\text { bahwa telah } \\
\text { berhasil mengurangi } \\
\text { saldo. }\end{array}$ \\
\hline 8 & Change Password & 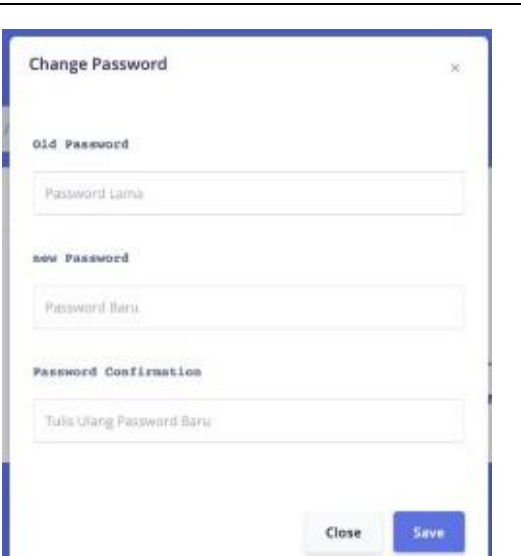 & $\begin{array}{l}\text { Muncul alert untuk } \\
\text { menginput } \\
\text { password lama dan } \\
\text { menggantinya } \\
\text { dengan password } \\
\text { baru. }\end{array}$ \\
\hline 9 & $\begin{array}{l}\text { Gagal Change } \\
\text { Password }\end{array}$ & Gagal! Password minimal 8 karakter. & $\begin{array}{l}\text { Muncul alert } \\
\text { bahwa password } \\
\text { tidak } \\
\text { ketentuan. }\end{array}$ \\
\hline 10 & Change password & Sukses! Password Berhasil Diubah. & $\begin{array}{l}\text { Password berhasil } \\
\text { diubah. }\end{array}$ \\
\hline
\end{tabular}

Sumber: Hasil Penelitian (2021)

Pengujian keseluruhan sistem adalah pengujian gabungan antara pengujian sistem perangkat keras (hardware) dan pengujian perangkat lunak (software) seperti pada tabel 4.

Tabel 4. Tabel Report Hasil Pengujian Keseluruhan Sistem

\begin{tabular}{lcccccc}
\hline Komponen uji & $\begin{array}{c}\text { Teknik } \\
\text { Pengujian }\end{array}$ & Jarak & Status & $\begin{array}{c}\text { Dashboard } \\
\text { Data } \\
\text { Barang }\end{array}$ & LCD & $\begin{array}{c}\text { Masuk } \\
\text { Database }\end{array}$ \\
\hline Sensor RFID & $\begin{array}{c}\text { Deteksi } \\
\text { Object }\end{array}$ & $\begin{array}{c}0-2 \\
\mathrm{~cm}\end{array}$ & Berhasil & Ya & Ya & Ya \\
& & & & & \\
\hline
\end{tabular}

Sumber: Hasil Penelitian (2021)

\section{Kesimpulan}

Berdasarkan hasil penelitan dan pembahasan yang sudah dilakukan, maka dapat ditarik kesimpulan sebagai berikut (a) Sistem pembayaran otomatis berbasis contactless smartcard telah dibuat menggunakan NodeMCU esp8266 dengan memanfaatkan RFID mifare522 sensor sebagai pendeteksi tag sehingga dapat memudahkan proses transaksi jual beli dikantin SMK Taman Harapan; (b) Monitoring dapat menggunakan website dengan data 
yang sudah otomatis tersimpan dalam database; (c) Website dibuat untuk mengetahui informasi user kantin dan admin serta history transaksi disimpan ke database secara realtime.

\section{Daftar Pustaka}

Aziz, K. H. (2015). Rancang bangun aplikasi e-money menggunakan nfc dengan jaringan internet pada payment carwash 123. 1, 130-135.

Dewobroto, W. (2005). Aplikasi Rekayasa dan Kontruksi dengan Visual Basic 6.0. Elex Media Komputindo.

Efendi, Y. (2018). Internet Of Things (lot) Sistem Pengendalian Lampu Menggunakan Raspberry $\mathrm{Pi}$ Berbasis Mobile. Jurnal IImiah IImu Komputer, 4(1), 19-26. https://doi.org/10.35329/jiik.v4i1.48

Jadid, A. (2017). Rancang Bangun Sistem Absensi Perkuliahan Auto Id Berbasis RFID Yang Terintegrasi Dengan Database Berbasis Web. Jurnal Karya IImiah Teknik Elektro, 2(2), 59-69.

Maharto, \& Ambarita, A. (2012). Metodologi Penelitian Sistem Infromasi.

Paulus, William, Panggabean, V. O., \& Pandi, F. (2013). Sistem Absensi Berbasis Radio Frequency Identification (RFID) Pada Mikroskil. JSM STMIK Mikroskil, 14(2), 129-138.

Syaddad, H. N. (2017). Rancang Bangun Digital Archiving Di Perguruan Tinggi Menggunakan Metode Prototype Model Studi Kasus: Universitas Suryakancana. Media Jurnal Informatika, 9(1), 49-57.

Utomo, S., Utomo, D., \& Yohanes, B. (2016). Sistem e-Money Berbasis Contactless Smartcard dengan Teknologi RFID. Techné: Jurnal IImiah Elektroteknika, 15, 67-75. https://doi.org/10.31358/techne.v15i01.142

Wicaksono, M. F. (2017). Implementasi Modul Wifi Nodemcu Esp8266 Untuk Smart Home. Jurnal Teknik Komputer Unikom-Komputika, 6(1), 9-14.

Zikri, M., Muhaimin, \& Aidi, F. (2018). Perancangan Alat Pembayaran Otomatis Pada Coffee Shop Menggunakan Debet RFID Berbasis Arduino. Jurnal Tekno, Vol. 2(1), 42-50. 